\title{
Edukasi Pola Makan pada Orang dengan HIV/Aids (ODHA) di Kota Ternate
}

\author{
Suryani Mansyur ${ }^{1}$, Diah Merdekawati Surasno ${ }^{1 凶}$, Agustin Rahayu ${ }^{1}$, dan Andiani ${ }^{1}$ \\ ${ }^{1}$ Staf Pengajar Fakultas Ilmu Kesehatan, Universitas Muhammadiyah Maluku Utara. Ternate, Indonesia. \\ Email : ryanimansyur@gmail.com,diah.surasno.86@gmail.com,agustinyayu21@gmail.com,andianimahbub@gmail.com \\ ${ }^{\square}$ Korespondensi : Diah merdekawati Surasno, Universitas Muhammadiyah Maluku Utara. Ternate, Indonesia, \\ Email : diah.surasno.86@gmail.com
}

\begin{abstract}
ABSTRAK
Berdasarkan United Nations Programme on HIV/AIDS (UNAIDS) Global Statistics Pada tahun 2018 terdapat 1,8 juta orang menjadi terinfeksi HIV baru. Orang yang hidup dengan HIV/ AIDS (ODHA) dari 75\% mengetahui status HIV merekadan 940.000 orang meninggal karena penyakit terkait AIDS .Pada tahun 2018 penderita HIV sebanyak 45 orang sedangkan AIDS adalah 15 orang. Jumlah ODHA yang ditemukan dengan pengobatan ART sampai Maret 2021 di Maluku Utara adalah 49 orang. Gangguan gizi pada ODHA umumnya terlihat pada penurunan berat badan (wasting). Oleh karena itu, perlu upaya intervensi pola makan yang baik pada ODHA untuk meningkatkan kualitas hidupnya. Kegiatan pengabdian bertujuan untuk mengedukasi ODHA tentang pola makan yang sehat dan bergizi seimbang. Metode yang dilakukan dengan konseling gizi dan pemberian menu diet untuk ODHA yaitu tinggi energi, tinggi protein dan lemak cukup. Kesimpulan: Frekuensi kebiasaan makan pada ODHA di Kota Ternate untuk makanan pokok yaitu yaitu paling sering $>1 \mathrm{x} /$ hari berupa Nasi sebanyak $70 \%$, konsumsi mie $40 \%$, Jagung 30\%; berbahan lauk pauk paling sering $(>1 \mathrm{x} / \mathrm{hr})$ adalah Ikan (80\%), telur (50\%), dan Tempe (40\%). Berbahan sayuran berupa Sayur bayam, Sawi dan Kacang Panjang sebanyak 4 orang (40\%), dan frekuensi makan buah- buahan paling sering 4$6 \mathrm{x} / \mathrm{hr}$ yaitu buah semangka dan jeruk sebanyak 5 orang (50\%), dan 1-3x minggu konsumsi Apel sebanyak 4 orang (40\%). Orang dengan HIV/AIDS sebaiknya selalu menjaga kesehatan dan asupan gizi yang baik untuk meningkatkan kualitas hidupnya di masyarakat.
\end{abstract}

Keyword: ODHA, Pola Makan, Edukasi

\section{PENDAHULUAN}

Acquired immunodeficiency Syndrome (AIDS) merupakan penyakit yang menyerang sistem imun tubuh yang disebabkan dari Human Immunodeficiecy Virus (HIV). Infeksi HIV ini menyebabkan menurunnya kemampuan tubuh untuk melawn penaykit, terutama penyakit infeksi sehingga tubuh sangat mudah untuk sakit dan akhirnya akan menyebabkan kematian.

Prevalensi HIV/AIDS di seluruh dunia terus mengalami peningkatan. Berdasarkan United Nations Programme on HIV/AIDS (UNAIDS) Global Statistics Pada tahun 2018 tercatat 36,9 juta orang di dunia hidup dengan HIV, dengan 35,1 juta orang dewasa di dunia hidup dengan HIV dan 1,8 juta anak - anak ( $<15$ tahun). Terdapat 1,8 juta orang menjadi terinfeksi HIV baru. Orang yang hidup dengan HIV/ AIDS (ODHA) dari 75\% mengetahui status HIV mereka dan sekitar 9,4 juta orang tidak tahu bahwa mereka hidup dengan HIV, dan 940.000 orang meninggal karena penyakit terkait AIDS (Data UNAIDS, 2018). Pada tahun 2018 penderita HIV sebanyak 45 orang sedangkan AIDS adalah 15 orang. (Dinas Kesehatan Kota Ternate, 2018). Jumlah ODHA yang ditemukan dengan pengobatan ART sampai Maret 2021 di Maluku Utara adalah 49 orang. ( Dirjen P2P Kemenkes, 2021).

Status Gizi sangat berkaitan erat dengan infeksi HIV, karena keduanya mempunyai hubungan dua arah. Pasien HIV- AIDS seringkali mengalami penurunan nafsu makan karena adanya penururnan system imun. Akibatnya orangan HIV- AIDS (ODHA) rentan terhadap malnutrisi . Gangguan gizi pada ODHA umumnya terlihat pada penurunan berat badan (wasting). Oleh karena itu, perlu upaya intervensi pola makan yang baik pada ODHA untuk meningkatkan kualitas hidupnya. 


\section{METODE PELAKSANAAN}

Kegiatan pengabdian Masyarakat ini melibatkan kelompok ODHA binaan LSM Makududara yaitu kelompok BRSODHA Wasana Bahagia Kota Ternate. Peserta yang hadir sebanyak 10 orang.

Adapun tahap kegiatan :

1. Tahap Persiapan

Pada tahapan ini,diawali dengan kegiatan perizinan untuk melaksanakan kegiatan pengabdian masyarakat dan bekerjasama dengan LKS Makududara.

2. Tahap Pelaksanaan

Pada tahapan pelaksanaan, diawali dengan pengukuran status gizi dan Wawancara frekuensi makan kemudian dilanjutkan Edukasi gizi. kegiatan ini dilaksanakan oleh 3 orang dosen gizi dan dibantu oleh mahasiswa sebanyak 2 orang.

3. Tahap Evaluasi

Pada tahap ini, kegiatan pengabdian masyarakat dievaluasi dengan pemberian contoh menu diet yang diberikan saat konseling gizi serta komitmen dari ODHA untuk memulai pola makan yang sehat dan bergizi seimbang .

\section{HASIL DAN PEMBAHASAN}

Wawancara frekuensi makan berlangsung selama 1 hari dengan diawali pengukuran status gizi pada ODHA yang kemudian dilanjutkan konseling gizi . Jumlah klien yang dikonseling adalah sebanyak 10 orang. Adapun hasil yang diperoleh saat pengukuran status gizi dan konseling, Dapat dilihat pada tabel 1 .

Tabel 1. Distribusi Status Gizi berdasarkan IMT pada ODHA di Kota Ternate

\begin{tabular}{ccc}
\hline Status Gizi & n & \% \\
\hline Kurus & 1 & 10 \\
Normal & 5 & 50 \\
Gemuk & 4 & 40 \\
\hline Total & $\mathbf{1 0}$ & $\mathbf{1 0 0}$
\end{tabular}

Sumber: Data Primer, 2022

Tabel 1 menunjukkan bahwa status Gizi pada ODHA yang mengikuti konseling gizi sebanyak 5 orang (50\%) status gizi normal, gemuk sebanyak 4 orang (40\%), dan kurus sebanyak 1 (10\%).

Tabel 2. Distribusi Frekuensi Makan berbahan Makanan Pokok pada Orang dengan HIV Aids di kota Ternate

\begin{tabular}{lcc}
\hline \multicolumn{1}{c}{$\begin{array}{c}\text { Frekuensi Makanan } \\
\text { Pokok }\end{array}$} & n & \% \\
\hline Nasi & 7 & \\
$>1 \mathrm{x} / \mathrm{hr}$ & 2 & 70 \\
1x/hr & 1 & 20 \\
$1-3 \mathrm{x} / \mathrm{mg}$ & $\mathbf{1 0}$ & 10 \\
\hline Total & & $\mathbf{1 0 0}$ \\
\hline Jagung & 3 & 30 \\
$>1 \mathrm{x} / \mathrm{hr}$ & 5 & 50 \\
$1-3 \mathrm{x} / \mathrm{mg}$ & 2 & 20 \\
1x/bln & $\mathbf{1 0}$ & $\mathbf{1 0 0}$ \\
Total & & \\
\hline Sagu & 1 & 10 \\
$>1 \mathrm{x} / \mathrm{hr}$ & 2 & 20 \\
$1 \mathrm{x} / \mathrm{hr}$ & 2 & 20 \\
$4-6 \mathrm{x} / \mathrm{hr}$ & 2 & 20 \\
1x/blh & 3 & 30 \\
1x/thn & 10 & 100 \\
\hline Total & & \\
\hline Singkong & 2 & 20 \\
$>1 \mathrm{x} / \mathrm{hr}$ & 3 & 30 \\
1x/hr & & \\
\hline
\end{tabular}




\begin{tabular}{|c|c|c|}
\hline $1-3 x / m g$ & 1 & 10 \\
\hline 1x/bln & 2 & 20 \\
\hline $1 \mathrm{x} /$ thn & 2 & 20 \\
\hline Total & 10 & 100Te \\
\hline \multicolumn{3}{|l|}{ Roti } \\
\hline$>1 \mathrm{x} / \mathrm{hr}$ & 3 & 30 \\
\hline $1 \mathrm{x} / \mathrm{hr}$ & 3 & 30 \\
\hline $4-6 x / m g$ & 1 & 10 \\
\hline $1-3 x / m g$ & 2 & 20 \\
\hline $1 \mathrm{x} / \mathrm{thn}$ & 1 & 10 \\
\hline Total & 10 & 100 \\
\hline \multicolumn{3}{|l|}{ Mie } \\
\hline$>1 \mathrm{x} / \mathrm{hr}$ & 4 & 40 \\
\hline 1x/hr & 3 & 30 \\
\hline $1-3 \mathrm{x} / \mathrm{mg}$ & 1 & 10 \\
\hline $1 \mathrm{x} / \mathrm{thn}$ & 2 & 20 \\
\hline Total & 10 & 100 \\
\hline
\end{tabular}

Tabel 2 menunjukkan bahwa orang dengan HIV-AIDS mengkonsumsi makanan berbahan makanan pokok lebih sering ( $>1 \mathrm{x} / \mathrm{hr}$ ) yaitu Nasi sebanyak $70 \%$, kemudian konsumsi mie $40 \%$ kemudian Jagung 30\%.

Tabel 3. Distribusi Frekuensi Makan Berbahan Lauk-Pauk Pada Orang dengan HIVAIDS di Kota Ternate

\begin{tabular}{|c|c|c|}
\hline $\begin{array}{c}\text { Frekuensi Makan } \\
\text { Lauk Pauk }\end{array}$ & $\mathbf{n}$ & $\%$ \\
\hline \multicolumn{3}{|l|}{ Ikan } \\
\hline$>1 \mathrm{x} / \mathrm{hr}$ & 8 & 80 \\
\hline $4-6 \mathrm{x} / \mathrm{hr}$ & 2 & 20 \\
\hline Total & 10 & 100 \\
\hline \multicolumn{3}{|l|}{ Ayam } \\
\hline$>1 \mathrm{x} /$ hari & 1 & 10 \\
\hline $1 \mathrm{x} / \mathrm{hr}$ & 2 & 20 \\
\hline $4-6 x / h r$ & 1 & 10 \\
\hline $1-3 x / m g$ & 4 & 40 \\
\hline $1 \mathrm{x} / \mathrm{bln}$ & 2 & 20 \\
\hline Total & 10 & 100 \\
\hline \multicolumn{3}{|l|}{ Daging Sapi } \\
\hline$>1 \mathrm{x} / \mathrm{hr}$ & 1 & 10 \\
\hline $1 \mathrm{x} / \mathrm{hr}$ & 1 & 10 \\
\hline $4-6 x / h r$ & 1 & 10 \\
\hline 1x/bln & 2 & 20 \\
\hline $1 \mathrm{x} /$ thn & 5 & 50 \\
\hline Total & 10 & 100 \\
\hline \multicolumn{3}{|l|}{ Telur } \\
\hline$>1 \mathrm{x} / \mathrm{hr}$ & 5 & 50 \\
\hline 1x/hr & 1 & 10 \\
\hline $4-6 \mathrm{x} / \mathrm{hr}$ & 2 & 20 \\
\hline $1-3 x / m g$ & 2 & 20 \\
\hline Total & 10 & 100 \\
\hline \multicolumn{3}{|l|}{ Tempe } \\
\hline$>1 \mathrm{x} / \mathrm{hr}$ & 4 & 40 \\
\hline $1 \mathrm{x} / \mathrm{hr}$ & 1 & 10 \\
\hline $4-6 x / m g$ & 3 & 30 \\
\hline $1-3 \mathrm{x} / \mathrm{mg}$ & 1 & 10 \\
\hline $1 \mathrm{x} / \mathrm{bln}$ & 1 & 10 \\
\hline Total & 10 & 100 \\
\hline \multicolumn{3}{|l|}{ Tahu } \\
\hline$>1 \mathrm{x} / \mathrm{hr}$ & 3 & 30 \\
\hline $1 \mathrm{x} /$ hari & 2 & 20 \\
\hline
\end{tabular}




\begin{tabular}{lcc}
\hline $4-6 \mathrm{x} / \mathrm{hr}$ & 3 & 30 \\
$1-3 \mathrm{x} / \mathrm{mg}$ & 2 & 20 \\
\hline Total & $\mathbf{1 0}$ & $\mathbf{1 0 0}$ \\
\hline & & \\
Udang & 1 & 10 \\
$>1 \mathrm{x} / \mathrm{hr}$ & 1 & 10 \\
$1 \mathrm{x} / \mathrm{hr}$ & 1 & 10 \\
$4-6 \mathrm{x} / \mathrm{hr}$ & 1 & 10 \\
$1 \mathrm{x} / \mathrm{blh}$ & 6 & 60 \\
$1 \mathrm{x} / \mathrm{thn}$ & $\mathbf{1 0}$ & $\mathbf{1 0 0}$ \\
\hline Total & & \\
\hline \multicolumn{1}{c}{ Sumber : Data Primer, 2022} & &
\end{tabular}

Tabel 3 menunjukkan bahwa kebiasaan makan ODHA mengkonsumsi makanan berbahan lauk pauk paling sering $(>1 \mathrm{x} / \mathrm{hr}$ ) adalah Ikan (80\%), telur (50\%), dan Tempe (40\%). Sedangkan konsumsi Ayam hanya dikonsumsi 1-3x/minggu sebanyak 40\%, daging sapi hanya $1 \mathrm{x} /$ tahun sebanyak $50 \%$.

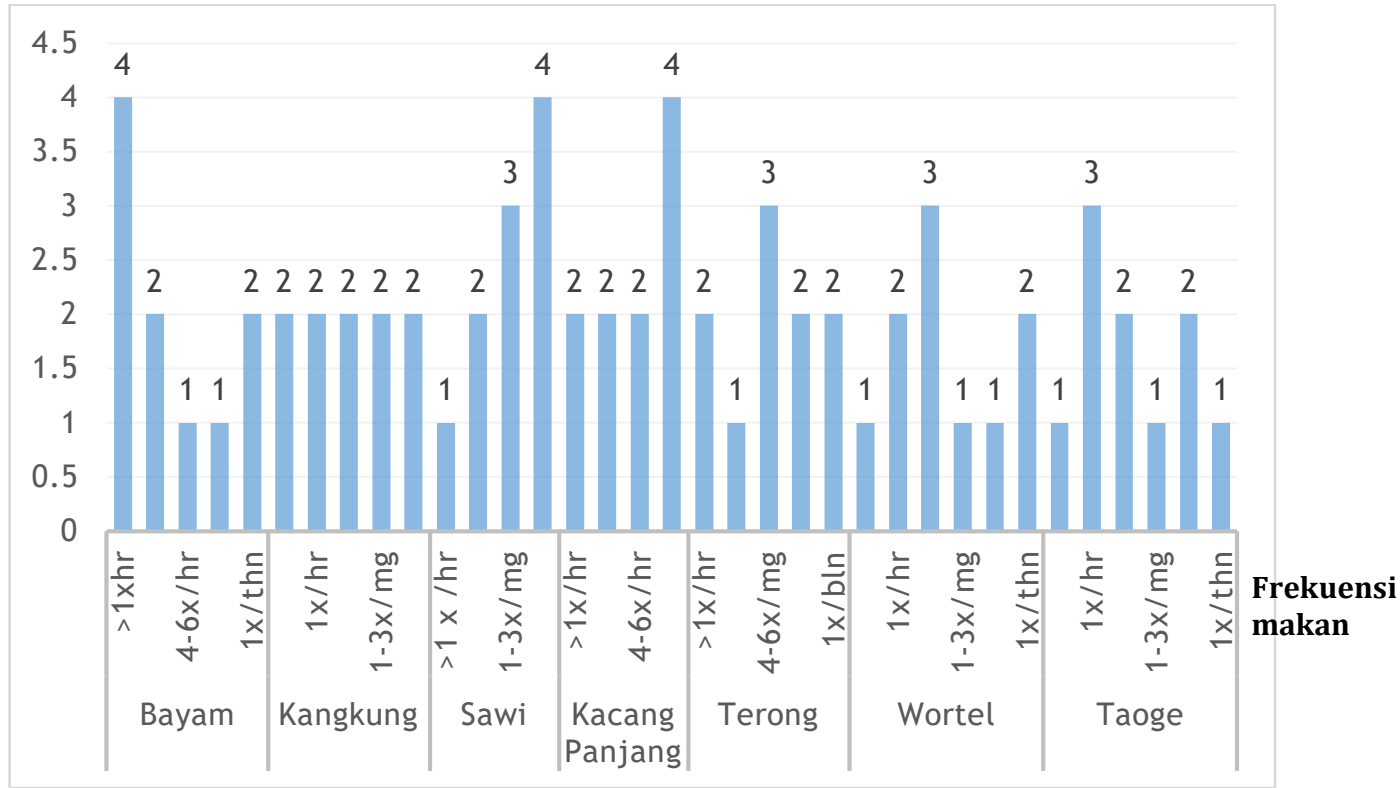

Gambar 1. Frekuensi Makan Berbahan Sayuran Pada Orang dengan HIV- Aids di kota Ternate, Sumber : Data Primer, 2022

Grafik pada Gambar 1. menunjukkan bahwa Frekuensi makan berbahan Sayuran pada orang dengan HIV- AIDS paling sering $>1 \mathrm{x} / \mathrm{hr}$ adalah Sayur bayam, Sawi dan Kacang Panjang sebanyak 4 orang (40\%), Terong dan wortel paling sering dikonsumsi 4-6x/hr sebanyak 3 orang (30\%). 


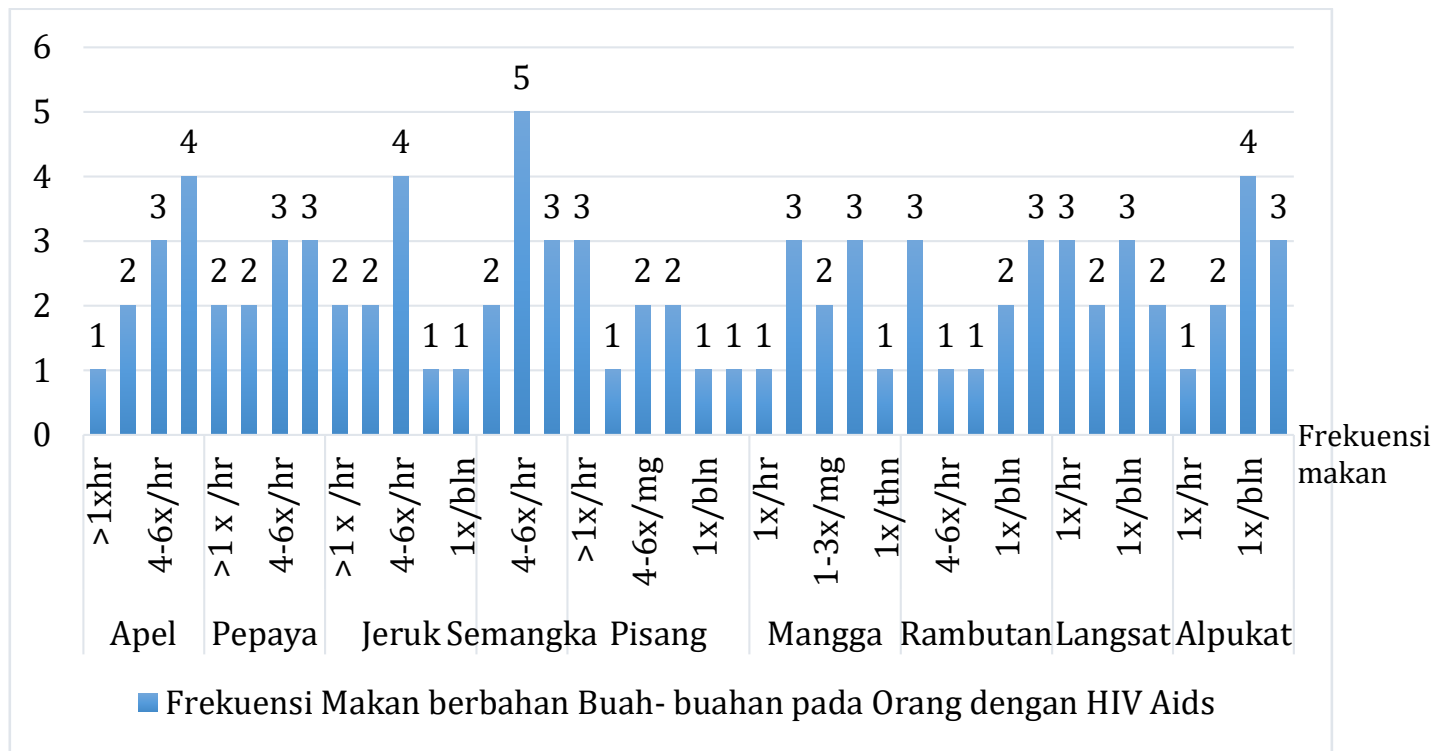

Gambar 2. Frekuensi Makan Buah-buahan Pada Orang dengan HIV- Aids di kota Ternate,

Sumber : Data Primer, 2022

Berdasarkan grafik pada Gambar 2, terlihat bahwa frekuensi makan buah- buahan pada ODHA paling sering 4-6x/hr yaitu buah semangka dan jeruk sebanyak 5 orang (50\%), dan 1-3x minggu konsumsi Apel sebanyak 4 orang (40\%). Adapun buah- buahan paling jarang dikonsumsi $(1 / / \mathrm{bln})$ adalah Alpukat sebanyak 4 orang (40\%), Pepaya , Rambutan , dan langsat masing- masing sebanyak 3 orang $(30 \%)$.

Setelah diketahui Pola makan atau kebiasaan makan dari ODHA, maka kemudian dilakukan konseling gizi dengan melakukan tanya jawab terkait masalah gizi yang dialami. Intervensi gizi melalui pemberian informasi terkait contoh menu diet yang bisa dilakukan oleh ODHA yaitu Tinggi Energi, tinggi protein dan lemak Cukup. Adapun Contoh Menu Diet:

Tabel 4. Contoh Menu Diet Orang Dengan HIV-AIDS

\begin{tabular}{|c|c|c|}
\hline Waktu & Menu & Bahan Makanan \\
\hline \multirow[t]{5}{*}{ Hari 1} & Makan pagi & Bubur Ayam, Buah pisang, teh manis \\
\hline & Snack & ONS (nurtrican) \\
\hline & Makan siang & $\begin{array}{l}\text { Nasi tim, pepes daging, tempe } \\
\text { bacem,sayur asem, Salad Buah (melon, } \\
\text { semangka, apel, anggur, mayones, keju) }\end{array}$ \\
\hline & Snack sore & ONS (Nutrican) \\
\hline & Makan Malam & $\begin{array}{l}\text { Lontong, Soto ayam, Tim tahu, Tauge, jus } \\
\text { jeruk. }\end{array}$ \\
\hline \multirow[t]{5}{*}{ Hari 2} & Makan pagi & $\begin{array}{l}\text { Nasi, telur dadar, setup buncis wortel, } \\
\text { susu }\end{array}$ \\
\hline & Snack & Bubur Kacang hijau \\
\hline & Makan siang & $\begin{array}{l}\text { Nasi, ikan goreng, telur balado, sambal } \\
\text { goreng tahu, sayur sup wortel }\end{array}$ \\
\hline & Snack sore & Agar- agar \\
\hline & Makan malam & $\begin{array}{l}\text { Nasi, empal daging, oseng- oseng tempe, } \\
\text { sayur bening bayam, pepaya }\end{array}$ \\
\hline \multirow[t]{5}{*}{ Hari 3} & Makan pagi & $\begin{array}{l}\text { Nasi , Tempe goreng, Cah kangkung, } \\
\text { Semangka }\end{array}$ \\
\hline & Snack & Kue dan teh \\
\hline & Makan siang & $\begin{array}{l}\text { Nasi, Ikan tuna saus manis, tumis terong, } \\
\text { Pisang }\end{array}$ \\
\hline & Snack sore & Pudding coklat \\
\hline & Makan Malam & $\begin{array}{l}\text { Jagung rebus, tahu balado, sayur bening, } \\
\text { pisang. }\end{array}$ \\
\hline
\end{tabular}


Tabel 5. Bahan Makanan yang Dianjurkan dan Tidak dianjurkan

\begin{tabular}{lll}
\hline \multicolumn{1}{c}{ Bahan Makanan } & Dianjurkan & \multicolumn{1}{c}{ Tidak Dianjurkan } \\
\hline Sumber karbohidrat & $\begin{array}{l}\text { Semua bahan makanan kecuali } \\
\text { yang menimbulkan gas }\end{array}$ & $\begin{array}{l}\text { Ubi Jalar, Singkong dll } \\
\text { yang menimbulkan gas }\end{array}$ \\
\hline Sumber Protein hewani & $\begin{array}{l}\text { Susu, telur, daging, ayam tidak } \\
\text { berlemak }\end{array}$ & $\begin{array}{l}\text { Daging, kulit ayam dan } \\
\text { bagian ayam yang } \\
\text { berlemak }\end{array}$ \\
\hline Sumber Protein nabati & Tempe, tahu, dan kacang hijau & Kacang merah \\
\hline Sumber Lemak & Minyak, margarin,santan, kelapa & $\begin{array}{l}\text { Semua makanan yang } \\
\text { dalamggi lemak (digoreng, } \\
\text { bersantan tinggi) }\end{array}$ \\
\hline Sayuran & $\begin{array}{l}\text { Sayuran yang tidak menimbulkan } \\
\text { gas, seperti labu kuning, wortel, } \\
\text { bayam, kangkung, buncis, kacang } \\
\text { Panjang, dan tomat }\end{array}$ & $\begin{array}{l}\text { Sayuran menimbulkan } \\
\text { seperti kol, sawi dan } \\
\text { metimun }\end{array}$ \\
\hline Papaya, pisang, jeruk, apel & Nangka dan durian \\
\hline Bumbu & Bumbu yang tidak merangsang & $\begin{array}{l}\text { Cabe, Lada, asam cuka, } \\
\text { dan jahe }\end{array}$ \\
& $\begin{array}{l}\text { seperti bawang merah, bawang } \\
\text { putih, daun slaam, ketumbar. }\end{array}$ & \\
\hline
\end{tabular}

\section{PENUTUP}

Frekuensi kebiasaan makan pada ODHA di Kota Ternate , antara lain makanan pokok yaitu yaitu paling sering $>1 \mathrm{x} /$ hari berupa Nasi sebanyak 70\%, konsumsi mie $40 \%$, Jagung 30\%; Berbahan lauk pauk paling sering $(>1 \mathrm{x} / \mathrm{hr})$ adalah Ikan (80\%), telur (50\%), dan Tempe $(40 \%)$. Berbahan sayuran paling sering $>1 \mathrm{x} /$ hari berupa Sayur bayam, Sawi dan Kacang Panjang sebanyak 4 orang (40\%), dan Frekuensi makan buah- buahan paling sering 4-6x/hr yaitu buah semangka dan jeruk sebanyak 5 orang (50\%), dan 1-3x minggu konsumsi Apel sebanyak 4 orang (40\%). Adapun yang dapat disarankan kepada Orang dengan HIV/AIDS sebaiknya selalu menjaga kesehatan dan asupan gizi yang baik untuk meningkatkan kualitas hidupnya di masyarakat.

\section{DAFTAR PUSTAKA}

Acce Basri, 2018. Determinan social "Quality of life " Orang dengan HIV/ AIDS (ODHA). MPPKI (September, 2018) 104-111 Vol. 1. No. 3

Adisty. 2012. Asuhan Gizi Nutritional Care Process. Yogyakarta: Graha Ilmu

Almatsier S. 2004. Penuntun Diet edisi baru. Jakarta: PT Ikrar Mandiri Abadi.

2004. Dasar - dasar Ilmu Gizi. Jakarta: PT Raja Grafindo

Dinas Kesehatan Kota Ternate. 2018. Laporan kasus HIV AIDS. Ternate.

E Asra, Nani Supriyatni,2020. Suryani Mansyur. Stigma terhadap Orang dengan HIV dan AIDS (ODHA) pada Masyarakat di Kelurahan Kayu Merah Kota Ternate Tahun 2019. Jurnal Biosaintek vol 2 no 1 Januari 2020. Diakses tanggal 12 September 2020, available at http://www.jurnal.ummu.ac.id/index.php/BIOSAINSTEK/article/view/325

Kementrian Kesehatan. 2021. Laporan perkembanagan HIV AIDS dan Penyakit Infeksi Menular Seks (PIMS) Triwulan 1 tahun 2021.

Supariasa, Dian Handayani. 2019. Asuhan Gizi Klinik. Jakarta: EGC

\section{Lampiran dokumentasi kegiatan}




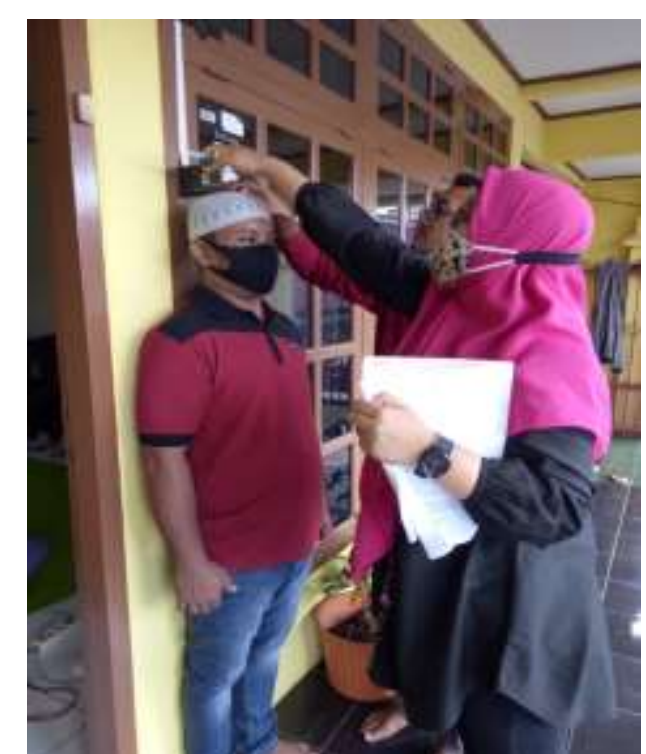

Pemeriksaan Antropometri untuk status gizi

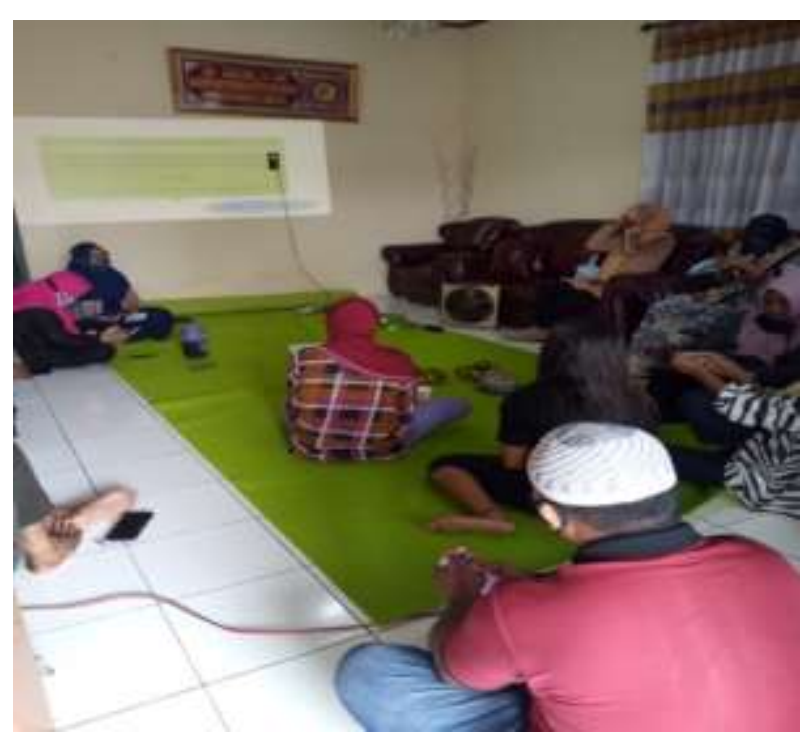

Edukasi Gizi

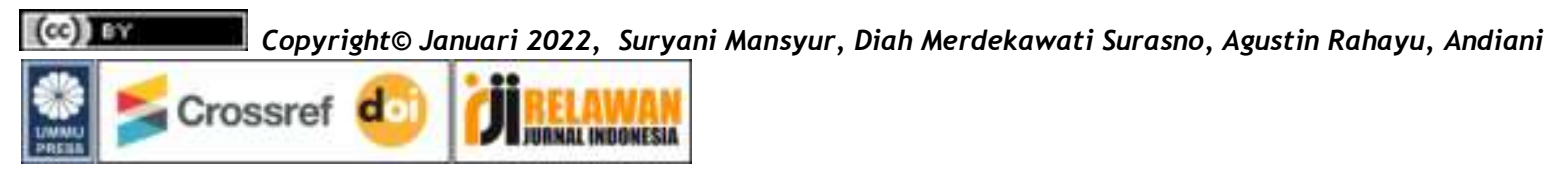

